The production of squatters as folk devils:

Analysis of a moral panic which facilitated the criminalisation of squatting in the Netherlands

\title{
PREPRINT
}

PUBLISHED IN DEVIANT BEHAVIOR Vol. 37, Iss.7, 2016

DOI: $10.1080 / 01639625.2016 .1145019$

\author{
E.T.C. Dee
}

deetc@riseup.net

\begin{abstract}
This article assesses recent improvements to Cohen's original formulation of the concept of moral panic. A case study is made of a moral panic generated in the Dutch media regarding three accusations made by the police concerning booby traps and weapons caches in the squats of Amsterdam. These claims, whilst shown to be fantastical in nature, gave credence to a ideological discursive formation which portrayed the squatters' movement as increasingly violent. Squatters were subsequently manufactured as folk devils requiring control via juridical repression, a process which resulted in the criminalisation of squatting in 2010.
\end{abstract}

Keywords: Urban Squatting, Moral Panic, Criminalisation, Netherlands, Critical Discourse Analysis, Folk devil, Ideological discursive formation 


\section{The production of squatters as folk devils:}

Analysis of a moral panic which facilitated the criminalisation of squatting in the Netherlands

\section{Introduction}

The concept of the moral panic is of continuing use in determining how people in a particular society react to what is perceived as deviance. This article examines improvements upon the original formulation of the concept (Cohen 1972) and a useful separation is made between normative and empirical judgements regarding the disproportionality of claims made about folk devils, drawing on recent work on moral panics (Critcher 2008; Dadusc and Dee 2015; Garland 2008; Goode and Yehuda 1994).

The criminalisation of squatting in the Netherlands was facilitated by a range of factors, one of which being a moral panic over several incidents which occurred at squat evictions in Amsterdam. In this article having first examined the general utility of the concept of moral panic, I will then apply it to the specific case study of the three evictions, furthering the analysis made by Hans Pruijt (2013a). Pruijt's article is another useful contribution to the growing interdisciplinary body of work on squatting, to which which he himself is a noted contributor (Aguilera 2013; Cattaneo and Martinez 2014; Dee 2013; Holm and Kuhn 2010; Martinez 2012; Martinez and Adell 2004; O'Mahony, O'Mahony and Hickey 2015; Owens, 2008, 2009; Platt 1999; Pruijt 2004, 2013a, 2013b; Uitermark 2004). However I argue below that his analysis of the moral panic needs to be deepened and expanded. I also disagree with him on several small points.

In the next section, the case study of the incidents is then used to evaluate the previously outlined approaches to moral panic theory and some suggestions made as to why the panic occurred when it did. Next I make some notes on the dangers of academics replicating uncritically the attitudes of a dominant ideological discursive formation, regarding some racist aspects of the moral panic. 


\section{Moral panic}

Stanley Cohen (2002:xii) writes in the introduction to the third edition of his seminal work Folk Devils and Moral Panics (first published 1972) that every successful panic has three requirements, namely:

1 A suitable enemy - "a soft target, easily denounced [..] clearly not the British police.”

2 A suitable victim - "someone with whom you can identify.”

3 A general consensus that the beliefs or actions being attacked are embraced by society as a whole and need to be protected.

Other scholars have sought to develop the concept further. Goode and Yehuda (1994:37-41) suggest that there are five features to a moral panic, namely:

1 Concern - "there must be a heightened level of concern over the behaviour of a certain group or category and the consequences that that behaviour presumably causes for one or more sectors of the society.”

2 Hostility - "there must be an increased level of hostility toward the group or category regarded as engaging in the behaviour or causing the condition in question.”

3 Consensus - "that the threat is real, serious, and caused by the wrongdoing group members and their behaviour.”

4 Disproportionality - "public concern is in excess of what is appropriate if concern were directly proportional to objective harm.”

5 Volatility - "the fever pitch that characterises a society during the course of a moral panic is not typically sustainable over a long stretch of time.” 
Critcher (2008:1128) sees this approach as a "related but distinct tradition from the USA," but I would argue that it is more of a development upon Cohen. This will be put it to the test with the case study. Finally, David Garland (2008:11) adds two additional factors to the schema of Goode and Yehuda, namely:

6 “The moral dimension of social reaction, particularly the introspective soul searching that accompanies these episodes.”

7 "The idea that the deviant conduct in question is somehow symptomatic."

Garland (2008:25) argues that "for a concept to be both meaningful and capable of precise application it has to operate within a network of other concepts, against which it can be distinguished or opposed.” He places moral panic in the context of social reaction and lists other concepts such as denial, cultural trauma and risk society reactions. Earlier in his article he mentions culture wars and I would add that to the list. Whilst praising its continuing utility, he also highlights concerns with the moral panic concept, some of which we shall examine next.

When Garland (2008:21) adds that the "assumption of proportionality immediately invites empirical disputes about the real nature and extent of the underlying problem," this is undoubtedly the case, since panics are often disputed by the various participants. If the problem can be addressed empirically, then the facts can be discussed objectively but when the issue becomes a normative one then "the pluralism of judgement is largely unavoidable” (Garland 2008:22).

Following on from this, if the moral judgement made is normative, then we must engage with the worrying issue that "what the analyst sees as a hysterical overreaction may be seen by the participants as an appropriate response to a deeply troubling moral evil” (Garland 2008:22). Here Garland is making an important point, since if a sociologist finds a social reaction disproportionate, this may say more about her world view than about the way things actually are. This has led some to discount the value of the moral panic entirely, yet the concept does hold explanatory power and it seems that there must be a middle way, to avoid throwing the baby out with the dishwater. Goode 
and Yehuda (1994:41) suggest that "though we must be cautious, modest, and tentative about making statements concerning what is real and true about events in the social world, we nonetheless can be fairly confident that some statements are more likely to be true than others.” Further, if we are not able to assess the problem empirically at all, then we cannot claim a moral panic exists, since there is no way to judge the disproportionality of the threat.

We shall return to this problem below, but first I will move to a case study of the Amsterdam squat evictions, from which we can make practical use of these theoretical concerns.

\section{The Amsterdam Incidents}

Amsterdam has a tradition of squatting which spans decades. By the time of the 2000s and up until the introduction of the new law, Amsterdam squat evictions had evolved into being a rather theatrical affair. There was an eviction wave (ontruimingsgolf) which occurred every three months in Amsterdam, always on a Tuesday (elsewhere in the country this was not the case). This meant that if there was an established squat, the occupants could rely on it surviving until at least the next eviction wave and from that point, if they were not evicted, then they were invariably secure for at least another three months. It did perhaps make sense for the police to organise all the evictions on the same day in order to save on resources, but it had produced a situation whereby evictions had become a ritualised event, in which squatters would know in advance about their eviction and thus spend days (possibly weeks) barricading buildings, doing so with the full knowledge that they would almost certainly be evicted when the police did actually turn up. There is a specialist unit of the Amsterdam police force with cutters, climbers and crane operators, which would arrive in force, close down the street and enter the building, often from the roof. The squatters in the building under threat of eviction would always resist to the utmost non-violently (with property destruction not being seen as violent since no person is being hurt) until the police had entered. Then they would stop resisting and almost always be allowed to go on their way. 
So it is important to note there was a format to evictions which was generally followed (with some exceptions). Uitermark (2004:687) refers to this code as an “informal 'pact' between squatters and the authorities - to quietly leave the building after a couple of water balloons or paintbombs have been thrown.” Further, he observes that in the contested eviction of the Kalenderpanden, the Mayor felt that the squatters had broken the code, demonstrating that the pact was fully understood on both sides of the debate.

What happened in 2007 was that the police broke this unwritten code and declared that two squats had been left booby-trapped (in 2008, the code was transgressed again when a building was illegally evicted in a show of power). For the squatters movement, the motivation for this was clear - the ongoing political push towards criminalisation needed support (and of course there were other incidents also). The three cases, also referred to by Pruijt (2013a), will be explored in more detail below.

\section{Bilderdijkstraat / Wilden Westen}

In the case of one squat, on Bilderdijkstraat (called by squatters Wilde Westen), a container full of combustible liquid was found in the evicted building, which the police then claimed to have been a firebomb booby trap. This accusation was reported by the press in March 2007, but challenged by the squatters. As time went on, the Mayor supported the police. The Greens in turn declared that they did not support his version of events and demanded clarifications.

As one squatter (J.West 2007) who had lived at the building said "We have always had a good relationship with our upstairs neighbours; we had a day nursery next door. Does anyone think we would want to blow it all up?" He also gave a direct response to the booby trap question: "Yes there was a jerry can with motor oil or something. That had been in the hall cupboard when we squatted it, it was in the hall cupboard on previous occasions when the cops cut open the door [...] and yes, it was still there when we left. For it was not ours, it belonged to the owner.” 
Another squatter asked in a letter to Het Parool newspaper for the police to supply a photograph of the alleged booby trap. A photograph has never been made available, "in the interest of the investigation,” according to a police spokesperson quoted in News from Amsterdam (2007). Further, nobody has ever been charged with any offence relating to the alleged bomb. Recently, this controversy was revisited when Leen Schaap, police commissioner, stated (in an interview with Saskia Naafs regarding the events of 2007) that "I found it a bridge too far. I wanted to avoid coming into a spiral of violence.” This statement was immediately challenged by an exsquatter from Bilderdijkstraat (Anon 2014), who accused Schaap of libel and slander, and made a formal complaint against him.

The unnamed author (Anon 2014) first declares that s/he was a spokesperson for the squat and never saw any boobytraps. S/he notes that no-one has ever been charged for any criminal matter relating to the eviction and remarks that s/he twice offered her/himself for arrest if any charges could be made (in June and November 2007). This would seem to contradict Pruijt's (2013a:14) assertion that in a meeting on 8/11/2007 "Some of the squatters told the politicians that they did not believe the account presented by the police, but added that they personally had not been present.” Finally, and in an indication that the author is well aware of the importance of these allegations made by the police in relation to the criminalisation of squatting, the squatter (Anon 2014) attests that:

These slanderous and defamatory statements have thus had a direct influence on the introduction of a controversial section of the law which, in my opinion, has deprived thousands of Dutch people of living protection and has caused serious damage to the social control of the vacancy in the Netherlands.

\section{Kerkstraat}


In the next case, in November 2007, police claimed after another eviction that a booby trap had been left in a squat on Kerkstraat comprising an electrical winch which could have collapsed the roof upon the unsuspecting entry squad. The mainstream media at first uncritically reported the incident, although later reports were more questioning, since the evicted squatters immediately rebutted the police story. They (Exbewoners Kerkstraat 2007) published a long piece on Indymedia in Dutch and English just days after the eviction. Using photographs, they demonstrated (Exbewoners Kerkstraat 2007) that all they had done was to barricade the room and leave "constructions that set off fire-extinguishers, blowing a cloud of dust into the room adjacent to the one the sensor that triggered the device was in.” The winch which the police had described as being primed to topple the roof was revealed to be "an electric motor from a toy train, used to set off the fire-extinguisher" and shown in photographs to be tiny.

Regarding these two booby trap cases, Pruijt (2013a:10) comments that:

In 2007, there were two incidents in Amsterdam in which the police reported that squatters had left booby traps in barricaded squats. In the first case the police said that a part of the roof had been rigged to fall down on police officers, in the second case that a gasoline-filled jerry can had been placed behind a steel plate with the idea that an explosion or fire would result when officers would cut through it with an angle grinder. Statements from within the squatter scene contradict this. Common in all the different accounts is, that the squatters barricaded the houses in such a way that they could leave while the police still would have difficulties getting in. This strategy left the power of interpretation entirely in the hands of the police.

However, it was the police here who changed the rules of the 'game.' The ritual of an eviction had been agreed through years of prior interaction between the squatters movement and the police, hence my reference previously to an unwritten code governing the procedure. In this case then, the 
police knowingly transgressed the code and abused their power to create an advantage for themselves. Thus, they certainly were able to encode a meaning which then was decoded uncritically by the mainstream media. Yet this was not because of any failing on the side of the squatters. Indeed, this bogus narrative was robustly challenged by the squatters (Exbewoners Kerkstraat 2007), who likened the claims of the police to the never substantiated accusation of 'weapons of mass destruction' in Iraq.

It is worth noting that in this case again, no-one was charged with any offence over these allegations and whilst it was perhaps an unwise stunt, it is clear that the squatters had not intended to harm anyone. A previous example cited by the squatters in their defence was the case (in 2005) when armed police were called to a squat on Prins Hendrikkade to investigate reports of a firearm which turned out to be nothing more than an electric drill (Exbewoners 2007).

As a further point, when Pruijt (2013a:14) writes “The squatters' reactions of disbelief [to the booby trap accusations] signal a normative communality with the authorities, ie that endangering police personnel was not acceptable,” I feel this misjudges the disbelief of the squatters, which was based on outrage at the completely fictious nature of the accusations made by the police, rather than anything to do with an opinion on violence against the police. Thus the booby trap incidents should not be seen as "exceptions in a series of protests, exceptions because they backfired" (Pruijt 2013a:14) but rather as textbook examples of how a moral panic is triggered. If, as Teun van Dijk (1987:198) contends, “unwittingly but professionally and ideologically, journalists represent the views of the authorities, if only by their selective use of sources and statements," then a moral panic was being created and squatters were being formulated as folk devils.

\section{Citex}

The third case referred to by Pruijt, in which 51 squatters were arrested and 'weapons' were found, was the illegal eviction of four houses at Eerste Oosterpark Straat on Friday May 23, 2008. One of 
the houses hosted a squat bar, called Citex. On Friday night, there was a birthday party and the police turned up, allegedly in response to a noise complaint. They asked for the identity of one person in the squat, which is illegal under Dutch law (one is required to supply identification papers if challenged on the street, but not in a private residence). The person refused to give identification and was arrested, but subsequently dearrested. In a response to this and in a display of force, the police then returned to illegally evict the bar plus all four of the houses, with 51 people being arrested in consequence (Citex Punx). As noted by Pruijt (2013a:20) in a footnote, the weapons discovered were some knives, bats and an air pistol, nothing along the lines of what the colourful language of an 'arms cache' would lead one to expect (i.e. no guns). Nevertheless, this 'weapons cache' was referred to by right-wing politicians and written about in the 'black book of squatting' (VVD 2008) as an example of the growing violence of the squatter movement.

Thus we can observe that these three incidents fed into a moral panic in which the group identity of squatters as responsible members of society was challenged and juridical action was seen as necessary in order to counter this new threat, despite the alleged violence and criminality of the squatters being based on no compelling evidence.

\section{Squatters as folk devils}

Having examined the three specific incidents in some detail, we can now move to an examination of how squatters were created as folk devils. Returning to the schema outlined by Cohen (2002:xii) it would seem that the status quo in Dutch society had been that the enemies were the squatters, the victims the people whose houses were squatted and the required consensus that squatters had no right to occupy houses and thus violate the rights of property owners, meaning that 'something had to be done' about squatters. This was the position of the hegemonic discourse although a strong counter-hegemonic discourse also circulated which framed squatters as responsible people who occupied properties in order to house themselves without waiting on housing lists or through 
deprivation, to conserve monumental buildings, to set up community projects or to make political actions, to employ Prujit's (2013b:21) fivefold categorisation of squatting. Surveys demonstrate that there was by no means a consensus that squatting was a bad thing for Amsterdam or indeed the Netherlands more generally (Pruijt 2013a:6). So as Pruijt (2013a:10) observes, the moral panic "unfroze a culture war in which the conservative side, driven partly by revanchist emotions, had a slight upper edge.”

However, Pruijt's comments on moral panics are quite brief. I think he is correct to state that a moral panic was created around a few incidents regarding squat evictions and that this helped to gain the proposed anti-squatting law (kraakverbod) enough public support to become law, many years after criminalisation had first been suggested. However, I think his account of the panic lacks depth and also fails to interrogate the panic critically, since the point is not drawn out that the panic was utilised rather cynically by politicians. Yes, the panic was used for “agenda-setting” as Pruijt (2013a:9) observes, but it is important to note that it was based on completely fictitious grounds, as I have described above.

Cohen (2002:123) discusses the universal conditions which apply to moral panics and suggests that there at least three, namely legitimating values, enterprise and power. In this particular case, some of the values which were mobilised in order to justify the panic were the right to private property, the need for society to obey the rules of so-called common decency and the respect for authority allied to the belief that criminalisation would put a stop to squatting, all foundational values for a democratic state such as the Netherlands. The enterprise of course came from the police representatives who first made statements about the eviction incidents and the politicians who subsequently took advantage of the situation to discuss the growing violence of the squatter movement. The power is represented by the police who were able to suggest rather biased interpretations of the incidents, the media which uncritically reported them and the politicians who responded to the stories by positing criminalisation as a means of controlling the squatters. Therefore, the accusations of booby traps served to generate a moral panic in which the victim was 
the police (and by extension society as a whole), the enemy was the violent squatter and the consensus was that 'something had to be done' to prevent this unacceptable level of threatened violence.

Thus we can see that Cohen's moral panic schema is still very useful as an explanatory tool for a recent moral panic, identifying the main actors and suggesting why the panic was successful. To return to the framework described by Goode and Yehuda (1994:37-41) and developed by Garland (2008:11) for the moral panic to be generated, there must have been:

1 Concern - there was indeed concern expressed by the police, mainstream media journalists and right-wing politicians about what they perceived as the increasing violence of the Dutch squatting movement.

2 Hostility - the level of hostility towards squatters certainly increased, as the stories circulated. 3 Consensus - there was a consensus that 'something had to be done' and criminalisation was the end result.

4 Disproportionality - this was rather hysterical reaction to claims which as we have seen had little basis in fact.

5 Volatility - the panic did blow up and burnt out quickly, although as we shall see the after effects continue to rumble on into the present day with the complaint against Schaap.

6 Moral dimension of social reaction - the panic did indeed provoke an extended public debate about how the squatters movement used to be peace-abiding and amenable. This was nostalgic in the extreme and conveniently forgot the violent confrontations (and foreigners) of the 1980s movement (more on that in the next section).

7 Squatters as symptom - being manufactured as folk devils meant the squatters were produced as the symptom of the problem, through a process of being othered as young, threatening, violent, disrespectful, foreign, different and so on. 
Points 1, 2, 3 and 5 all seem to have been covered sufficiently by Cohen's schema, so I will concentrate now on points 4 and 7, and return to point 6 in the next section.

To take the last point (number 7) first, it is useful to note the observation made by Critcher that moral panic theory can benefit from being allied to the perspectives provided by risk society thesis and discourse analysis (2008:1139). In a different work, Critcher comments that "discourse analysis has the potential to analyse the ways in which lingustic strategies serve to validate the definitions and responses characteristic of moral panics” (2006:168). With Deanna Dadusc, I (2015) have utilised Critical Discourse Analysis (inspired by the work of Norman Fairclough $(1985 ; 1993)$ ) in discussing the criminalisation of squatting in England and Wales, and the Netherlands. Building on Foucault's discourse analysis, Fairclough suggests (1985:751) that in relation to any issue different ideological discursive formations can be discerned, describing the collection of beliefs which lead people to think and act in a certain way about that issue. There can be hegemonic formations and resistant ones (and often one discourse formation dominates). In the case study above, it is clear that the dominant ideological discursive formation presented squatters as possessing deviant qualities. Likewise, in another article I (2013:258) discussed how squatters in England and Wales were 'othered' into threatening criminals, with no possible way in which to redeem themselves. As Critcher states, in the escalating hierarchy of discourse, they had become "the Other embodying evil” (2006:175).

As mentioned above, point 6 is dealt with in the next section and regarding proportionality (point 4), Goode and Yehuda (1994:40) note that for a moral panic the generation and dissemination of figures or numbers is extremely important - addicts, deaths, dollars, crimes, victims, injuries, illnesses - and most of the figures cited by moral panic “claims-makers” are wildly exaggerated. It would seem obvious in this case that the claims of life-threatening violence laid at the door of squatters were exaggerated and based on little hard evidence. The squatters involved in all three separate cases quickly challenged the claims, but were unable to refute them adequately since the 
dominant ideological formation was set firmly against squatters.

This brings us to the issue of proportionality as it intersects with the question of the allegiance of the sociologist. Squatters argued that the reaction of the police was disproportionate. This reaction was itself quickly seized upon by the mainstream media (which reported the allegations uncritically) and right-wing politicians (who were only to happy to have some more examples of squatter mayhem to add to their black book of squatting). I however would agree with the squatters analysis, since there is little empirical basis for the police allegations.

To take the accusations one by one:

*The so-called booby trap at Wilde Westen was immediately disputed by the squatters and is still a bone of contention. Whilst the container does appear to have existed, it was never intended as a bomb and was not put there by the squatters. The police have never provided any evidence and never charged anyone with any crime, despite several requests to do so.

*The alleged booby trap at Kerkstraat has been comprehensively disproved by photographic evidence.

*The Citex arms cache was really nothing of the sort and such an emotive description must have been intended to hint at much worse things.

Therefore the use of words like 'weapons' and 'bombs' was overly dramatic . This point also speaks to the issue of whether disproportionality is judged on empirical or normative grounds. In this specific case, it is clear the debate can be resolved empirically. This is why I can judge these events to constitute a moral panic, since:

It is only by knowing the empirical nature of a given threat that we are able to determine the 
degree of disproportion. The concept of the moral panic rests on disproportion. If we cannot determine disproportion, we cannot conclude that a given episode of fear or concern represents a case of a moral panic (Goode and Yehuda 1994:41).

I would also dispute the reasoning behind the panic on other grounds, but there is no need to do so when the facts speak for themselves, since it is clear that the threat was exaggerated by the police in all three cases. However, on that note (writing on the issue of gentrification and how it should be addressed by critical urban studies, but the point applies equally well here) Tom Slater (2009:306) argues that academics should work within an "analytical, political and moral framework which is rooted in housing as a question of social justice.” This dovetails well with slogans of the Dutch squatters movement such as 'housing is a right'. The criminalisation of squatting served the interests of the few and damaged the opportunities of the many, as was succinctly pointed out by the squatter (Anon 2014) from the Bilderdijkstraat in his/her complaint against Leen Schaap. Thus, it is worth spending a brief moment analysing how and why it came about.

There are many reasons as to why squatting was criminalised in 2010, when it had first been suggested as an issue which needed juridical control decades earlier. Squatters talk of the decline of the movement providing an opportunity for it to be attacked, but there are broader themes at work such as the shift to the right-wing in Dutch politics, the gentrification of cities in the Randstad, the increasing normalisation and control of urban life and last but not least, the continuing importance of private property rights in a capitalist society. Squatting, despite its recognised uses by city councils in the Netherlands as a provider of both accommodation and creative spaces, was an inconvenient loose end which needed tying up. The squatters movement, despite its decline, was a thorn in the side of government which could finally be pulled out. There is no single reason to explain this, more a concatenation of factors - a coalition of anti-squat companies, housing corporations, speculators and politicians with a right-wing agenda finally found enough weight on the seesaw of power to overthrow the old alliance of left-wing sympathisers, tolerant politicians, 
church-goers and homelessness campaigners. Asking the question why this occurred at a particular time gives no easy answers and will remain question for future historians, although it is interesting to note that squatting in England and Wales was also criminalised in residential buildings shortly afterwards, in 2012.

\section{Foreign bodies}

Here as an interlude I would like to examine another part of the story of how squatters were othered as folk devils. For as well as there bing a discourse which presented them as an increasingly violent menace, other intertwined discourses suggested that the squatting movement had lost its way from its principles established through struggle in the 1980s and also that increasing numbers of foreign squatters were attacking Dutch values. Pruijt (2013a:16) states that:

A more substantiated claim in the motivation [to criminalise squatting] is that increasingly, non-Dutch citizens, including touristic squatters from South and East Europe, were among the active squatters. The example given is a 2007 eviction at which individuals representing nine different foreign, but Western, nationalities were arrested. The conclusion attached was that Dutch policy should avoid attracting foreign squatters. It is true that squatting has internationalised. Van Gemert et al. (2009) estimate, in correspondence with police data, that about a third of the squatters in Amsterdam were foreign. Foreign squatters, because of their lack of roots in Dutch society, can easily be treated as undesirables that should and can be removed and prevented from coming; their presence facilitated the construction of revanchist discourse.

I would like to challenge the claim that the presence of foreign squatters allowed the new discourse to be created on the grounds that whilst the racist discourse certainly existed, the presence of 
foreign squatters in Amsterdam was certainly not a new thing. Lynn Owens has commented from the 1960s onwards the Amsterdam squatter scene has had a complex and shifting relationship with tourists and foreigners, which he tracks as a four-part process summarised as initial unity, separation, mutual antagonism and eventual reconciliation (Owens 2008). Whilst it may be true that a third of squatters in Amsterdam in 2009 were foreigners (Pruijt 2013a:16, drawing on the work of Dadusc et al.), it is also true that in the early 1980s there were more than 10,000 squatters (Owens 2009). Dadusc et al. (2009:23,47) estimate numbers in 1980 to have been as high as 20,000 and in 2009 to be between 1,500 and 2,000.

I would not like to claim that a third of these 10,000 to 20,000 squatters in the 1980 s were foreigners but I would insist that a sizeable minority were, a number which in all likelihood dwarfs the numbers of foreign squatters in Amsterdam in more recent times - even if a small sample (110 people) questioned by Dadusc et al. (2009: 63) contained 65\% foreign squatters. Hugo Priemus (2011:4) claims that squatters “in the 1980s were almost exclusively natives: ethnic minorities were not represented” but he bases his figures on his 1983 research into legalised squats, in which he found that $12 \%$ of people were not Dutch natives. That would make 677 people out of 5,644, surely not an insignificant number (Priemus 1983: 422).

Accurate information is scarce here, but as a final point, Uitermark and Nicholls (2013:9) mention that amongst the influx of migrant workers in the 1970s "a small yet vocal group imported into Amsterdam radical dissent cultivated in the resistance against the autocratic regimes of (first) Spain, Greece and Portugal, and (later) Morocco and Turkey.” Some of these activists were squatting, for example the Committee for Moroccan Workers occupied a canal house in 1975 (Uitermark and Nicholls 2013).

In any case, I think it is fair to conclude then that foreign squatters are not by any means a new phenomenon in Amsterdam and thus should not be blamed for a shift in discourse which was aimed at facilitating criminalisation. In the attempt to frame squatters as dangerous other, the slip into a racist discourse occurred as an easy option, not because of any specific actions by foreign squatters, 
who had actually always been a part of the squatting movement.

Additionally, this racist revanchist discourse turns out to be nothing new. Van Dijk (1987:285), writing in the 1980s about how the Dutch mainstream media reported the eviction of the Grote Wetering and subsequent events, affirms that "only the negative actions of the social opponents are emphasised.” Further, there tended to be a “disproportionate focus on violence, internal conflicts and the role of isolated actors (foreigners) and a neglect of social backgrounds, reasons and aims of social and political opponents or minorities” (1987:261). Thus, as way to construct squatters as a threatening other, the racist discourse of blaming foreign outsiders has been present since the 1980s at least. One would then hope that the revanchist approach would by now be easier to identify. Yet a dominant ideological discursive formation does not have to be truth-based to be successful. Referring back to Garland's point 6 in the previous section, 'the moral dimension of social reaction,' the important thing was that there was a sense of outrage that the squatters movement had neglected its honourable roots in the 1980s. Whilst this outrage conveniently ignored the violent protests around specific struggles such as the Vondelstraat, Grote Keyser and Lucky Luyk (Owens 2008), it was another component in the complex process by which squatters were othered as folk devils. Ultimately, it mattered not that squatters themselves contested this characterisation bitterly, since the damage was done and squatting was indeed later criminalised. The problem here for the squatters movement is that it was battling against hegemonic discourses which were both configured against them and were also specifically designed to counter strong anti-hegemonic discourses (Dee 2013:251).

\section{Conclusion}

When the criminalisation of squatting in the Netherlands occurred in 2010, this followed decades of debate. Many factors both internal and external to the squatting movement led to this occurrence, here we have focused upon the moral panic which arose regarding incidents at three evictions in 
Amsterdam. As Pruijt (2013a) has demonstrated, there were at least three other factors (revanchism, culture wars, creative city) which contributed significantly to criminalisation, but moral panic was certainly a necessary and important element.

My argument here has been that the moral panic was in fact based on very little hard evidence but reflected a hegemonic discourse which both shaped and was shaped by a biased narrative, thus causing both the police and the mainstream media to portray squatters as a dangerous other. These biases formed part of a dominant ideological discursive formation. This framework, engaged with and strengthening hegemonic discourses, eventually enabled criminalisation and indeed the juridical repression would most likely not have occurred otherwise.

Taking Cohen's original formulation of the moral panic and considering amendments provided by Garland and Goode and Yehuda, I applied it to the case study of the three incidents. We addressed an important issue about the sociologist's perspective and made a distinction between empirical and normative judgements. However, in talking about a moral panic, the disproportionality of the claims made against the group being manufactured as a folk devil must be considered and in this case, as I have shown, the claims were widely exaggerated (and never proven), thus they were disproportionate. Squatters were slandered and in the case of the Bilderdijkstraat at least, the debate is still rumbling on, whilst squatting itself has been criminalised. In this regard, Garland (2008:16) hits the nail on the head when he states "moral panics often seem ephemeral but over time their cumulative effect can be to create social divisions and redistribute social status as well as building infrastructures of regulation and control that persist long after the initial episode has run its course.” In this case, the dominant ideological discursive formation successfully othered squatters. Part of this discourse was racist, thus academics studying moral panics should take care not to replicate the attitudes of hegemonic discourses uncritically, since otherwise (whether by design or not), their work may end up supporting them.

As a final point, to show that this specific sort of panic can recur, I refer to the recent eviction of a house in Seattle, USA, in which 'fears of booby traps' led to the presence of a SWAT (special 
weapons and tactics) team. The local news report (KOMO staff 2012) quotes the Chief Deputy as saying "some communication had been received through social media that there might be some barricades going up, there might be booby traps inside the home." However, it goes on to record that “the sweep of the home didn't turn up any weapons or booby traps”. Also, in the context of the criminalisation of squatting in England and Wales, I (2013:258) documented how moral concerns about 'bad' squatters were raised in the mainstream media, produced by a racist ideological discursive formation.

Squatters in the Netherlands have been stereotyped as violent and criminal, in a moral panic which turned them into folk devils and resulted in legislative changes which now require the state to intervene when empty property is occupied. Additionally, a racist discourse arose which has othered squatters and manufactured a threat where none really existed. This process panders to stereotypes in an unacceptable manner. Clearly, this process conforms to more general patterns and as a closing remark, it would be interesting to compare the various different situations in which moral panics have been mobilised to facilitate repressive legislation. Critcher (2008) has provided an important beginning towards this goal and in his seven-part categorisation of moral panics, the discussion here would fit into the area of (youth) deviance. 


\section{References}

Aguilera, Thomas. 2013. "Squatting in Paris and the Ile-de-France Region: Diversity of Configurations and Relations with Public Authorities.” in Squatting in Europe: Radical Spaces, Urban Struggles, edited by Squatting Europe Kollective. Wivenhoe; New York; Brooklyn, NY: Minor Compositions.

Anon. 2007. “Police Conciliatory after 'booby Trap.’” News from Amsterdam.

Anon. 2014. “(Ex-)kraker WildeWesten Doet Aangifte van Smaad En Laster Tegen Leen Schaap.” Indymedia. Retrieved July 31, 2014 (https://www.indymedia.nl/node/22908).

Citex Punx. 2008. “Citex Squat Amsterdam Illegally Evicted.” Indymedia. Retrieved July 31, 2014 (http://www.indymedia.org.uk/en/2008/05/399604.html).

Cohen, Stanley. 2002. Folk Devils and Moral Panics: The Creation of the Mods and Rockers. Abingdon, Oxon ; New York: Routledge.

Critcher, Chas. 2003. Moral Panics and the Media. Buckingham ; Philadelphia: Open University Press.

Critcher, Chas. 2008. “Moral Panic Analysis: Past, Present and Future.” Sociology Compass 2(4):1127-44.

Dadusc, Deanna and E. T. C. Dee. 2015. “The Criminalisation of Squatting: Discourses, Moral Panics and Resistances in the Netherlands, England and Wales.” in Vulnerable Demons? Moral Rhetoric and the Criminalisation of Squatting, edited by David O’Mahony, Lorna O’Mahony, and Robin Hickey. London: Routledge.

Dadusc, Deanna, D. Siegel, C. Brouwers, R. Visser, and Frank van Gemert. 2009. Kraken in Amsterdam anno 2009. Amsterdam: VU Criminologie.

Danen, R. 2007. “Amsterdamse Politie Ziet Spoken.” Indymedia. Retrieved July 31, 2014 (https://www.indymedia.nl/nl/2007/11/48125.shtml).

Dee, E. T. C. 2013. “Moving towards Criminalisation and Then What? Examining Dominant Discourses on Squatting in England.” in Squatting Europe Kollective - Squatting in Europe: 
Radical Spaces, Urban Struggles, edited by Squatting Europe Kollective. Wivenhoe; New York; Brooklyn, NY: Minor Compositions.

van Dijk, Teun A. 2013. News Analysis: Case Studies of International and National News in the Press. Routledge.

Exbewoners Kerkstraat. 2007. “Verklaring Exbewoners Kerkstraat.” Indymedia. Retrieved July 31, 2014 (https://www.indymedia.nl/nl/2007/11/48163.shtml).

Fairclough, Norman. 1985. "Critical and Descriptive Goals in Discourse Analysis.” Journal of Pragmatics 9:739-63.

Fairclough, Norman. 1993. “Critical Discourse Analysis and the Marketisation of Public Discourse: The Universities.” Discourse Society 4(2):133-68.

Garland, David. 2008. “On the concept of moral panic.” Crime Media Culture 4(9):9-30.

Goode, Erich and Ben-Yehuda, Nachman. 1994. Moral Panics: The Social Construction of

Deviance. Second edition 2009. Oxford: John Wiley.

Holm, Andrej and Armin Kuhn. 2011. "Squatting and Urban Renewal: The Interaction of Squatter Movements and Strategies of Urban Restructuring in Berlin: Squatting and Urban Renewal in Berlin.” International Journal of Urban and Regional Research 35(3):644-58.

KOMO Staff. 2012. “SWAT Team Evicts 7 Squatting inside Central District Home.” KOMO News. Retrieved July 31, 2014 (http://www.komonews.com/news/local/137090818.html).

Martínez, Miguel A. 2013. “The Squatters’ Movement in Europe: A Durable Struggle for Social Autonomy in Urban Politics.” Antipode 45(4):866-87.

Naafs, S. 2014. “Kraker Is Leuke Tegenstander.” Parool.

O’Mahony, Lorna Fox, David O’Mahony, and Robin Hickey, eds. 2015. Vulnerable Demons?

Moral Rhetoric and the Criminalisation of Squatting. London: Routledge.

Owens, Lynn. 2008. "From Tourists to Anti-Tourists to Tourist Attractions: The Transformation of the Amsterdam Squatters’ Movement.” Social Movement Studies 7(1):43-59.

Owens, Lynn. 2009. Cracking under Pressure: Narrating the Decline of the Amsterdam Squatters' 
Movement. University Park, Pa: Pennsylvania State University Press.

Platt, Steve. 1999. "Home Truths: Media Representations of Homelessness.” in Social Policy, the Media and Misrepresentation, edited by B. Franklin. London: Routledge.

Priemus, Hugo. 1983. “Squatters in Amsterdam: Urban Social Movement, Urban Managers or Something Else?” International Journal of Urban and Regional Research 7(3):417-27.

Priemus, Hugo. 2011. "Squatters and Municipal Policies to Reduce Vacancy: Evidence from The Netherlands.” Pp. 1-6 in Workshop 11: Housing Regeneration and Maintenance: Towards an Environment-Friendly Housing Stock. Toulouse: European Network for Housing Research. Pruijt, Hans. 2004. “Squatting in Europe.” Pp. 35-60 in ¿Donde Esta las Llaves? El Movimiento

Okupa: Practicas y Contextos Socials, edited by Ramon Adell and Miguel Martinez. Madrid: La Catarata.

Pruijt, Hans. 2013a. "Culture Wars, Revanchism, Moral Panics and the Creative City. A Reconstruction of a Decline of Tolerant Public Policy: The Case of Dutch Anti-Squatting Legislation.” Urban Studies 50(6):1114-29.

Pruijt, Hans. 2013b. “Squatting in Europe.” in Squatting in Europe - Radical Spaces, Urban Struggles, edited by Squatting Europe Kollective. Wivenhoe; New York; Brooklyn, NY: Minor Compositions.

Uitermark, Justus. 2004. “The Co-Optation of Squatters in Amsterdam and the Emergence of a Movement Meritocracy: A Critical Reply to Pruijt.” International Journal of Urban and Regional Research 28(3):687-98.

Uitermark, Justus and Walter Nicholls. 2013. "From Politicization to Policing: The Rise and Decline of New Social Movements in Amsterdam and Paris.” Antipode 1-22.

VVD. 2006. “Zwartboek Kraken.” Retrieved July 31, 2014

(http://www.vvdamsterdam.nl/files/14b6f66fd1ca1/). 


\section{Author biography:}

E.T.C.Dee has written on media discourses surrounding the criminalisation of squatting in 'Squatting in Europe: Radical Spaces, Urban Struggles' (Minor Compositions) and with Deanna Dadusc in 'Vulnerable demons? Moral rhetoric and the criminalisation of squatting' (Routledge). He has also written on squatting as a social movement in 'The Squatters' Movement in Europe:

Everyday Commons and Autonomy as Alternatives to Capitalism' (Pluto).

More information - http://ucm.academia.edu/ETCDee. 